INTERNATIONAL JOURNAL OF RESEARCHES IN BIOSCIENCES, AGRICULTURE AND TECHNOLOGY

(C) VISHWASHANTI MULTIPURPOSE SOCIETY (Global Peace Multipurpose Society) R. No. MH-659/13(N)

www.vmsindia.org

\title{
EFFECT OF ORGANIC AND INORGANIC FERTILISERS ON SODIC VERTISOLS OF PURNA VALLEY (VIDARBHA) FOR GROWING COTTON
}

\author{
V. P. Babhulkar, P. R. Kadu, P. C. Pagar \\ College Of Agriculture, Nagpur- (M.S.) India \\ Deptt of Agril. Chemistry and Soil Science \\ Dr. Panjabrao Deshmukh Krishi Vidyapeeth,
} Akola, Maharashtra- 444104

\section{INTRODUCTION}

Vertisols of Purna valley are very deep, ill-drained and saline/sodic in nature, although salinity and sodicity are mainly confined to subsoil horizons (Sagare et al., 1991). Generally, salt affected soils are potentially productive, however, without integration of organic and inorganic amendments, these soils may not be productive on sustainable basis. The different amendments had variable effect on physicochemical properties of soil, however, gypsum found to be more effective in increasing hydraulic conductivity and decreasing clay dispersions (Verma and Gupta, 1985) and in removing $\mathrm{Na}^{+}$and reducing the $\mathrm{pH}$, ECe, ESP and increasing exch. $\mathrm{Ca}^{+*}$ and $\mathrm{Mg}^{++}$in soil (Patel and Singh, 1991). The present investigation was cavY $\backslash \mathrm{e}<\mathrm{i} \quad \mathrm{o} \backslash \mathrm{A}$ Vo study efficacy of various amendments in decreasing the salinity and sodicity of Sodic Vertisols and yield of cotton.

\section{MATERIALS AND METHODS}

A randomized block design filed study was conducted on Hy. Cotton (cv. PKV2) grown in Sodic Haplusterts of Purna Valley, of Vidarbha Region of Maharashtra. The experimental soil is a member of very fine montrnorillonitic, hyperthermic family of Sodic Haplusterts (pHs 8.8, ECe $2.8\left(\right.$ dSnrf $^{1}$ ), SARe 18 and $\mathrm{HC} 0.1$ ( $\left.\mathrm{cm} \mathrm{hr}{ }^{11}\right)$. Treatments included various gypsum levels (0,50 and 100\% GR), FYM @ 5 t ha'1, PMC @ 2.5 t ha'1, Gypsum 50\% GR + FYM@ 5 t ha'1 and Gypsum 50\% GR + PMC (2.5 $\mathrm{t}$ ha"1. Amendments were applied and incorporated in soils before sowing and recommended dose of fertilizer $(50 \mathrm{~kg} \mathrm{~N}+25 \mathrm{~kg}$ $\mathrm{P}_{2} \mathrm{O}_{5}+25 \mathrm{~kg} \mathrm{~K} \mathrm{~K}_{2} \mathrm{ha}{ }^{1}$ ) was applied through urea, single superphosphate and muriate of potash respectively. Soil characteristics including gypsum requirement and $\mathrm{HC}$ were determined as described by Richards (1954).

\section{RESULTS AND DISCUSSION}

Yield of Seed

Cotton
An incorporation of gypsum @ 50 and $100 \%$ GR enhanced significantly the seed cotton and stalk yield over control; although, both levels were at par (Table 1). Data further reflected that gypsum application @ 50\% GR when integrated with FYM @ 5t or PMC 2.5 t ha"1 found significantly superior in respect of yield of seed cotton and stalk over gypsum, FYM and PMC, alone. However, both combinations had more or less same effect. The increases in the seed cotton yield due to these combinations were about 68 per cent over control. Maximum monetary returns and B:C ratio were also accrued due to combine application of gypsum 50\% GR + PMC followed by gypsum @ 50\%.GR + FYM. integrated approach of chemical and biological amelioration found more beneficial in Vertisols than their individual application (Varade, et al., 1985). Addition of gypsum @ 50\% GR gave optimum returns and proved better than its split application in alkali loam soils, reported by Tiwari and Sharma (1989). An augmentation in the yield of crops due to various amendments could be attributed to suppression in various salinity and sodicity characteristics which resulted in increasing hydraulic conductivity of soil (Table 2).

\section{Changes in soil characteristics}

A decrease in pHs, ECe and increase in HC was noticed due to addition of gypsum, FYM, PMC and their combinations (Table 2). Application of gypsum @ 50 and 100\% GR decreased pHs, ECe, SARe and enhanced HC significantly over control. However, differences due to both the levels were found at par with each other. The combinations of gypsum @ 50\% GR + FYM or PMC further reduced the salinity and sodicity and augmented $\mathrm{HC}$ of soils. However, both the combinations had more or less similar, impact in reducing the salinity and sodicity of soils. These results corroborated with the findings of Shivakant and Rajkumar (1992). 


\section{Relationship of soil parameters with seed cotton yield}

A significant positive relationship of hydraulic conductivity ( $\left.\mathrm{r}=0.906^{* *}\right)$ and a highly significant but negative relationship of $\mathrm{pHs}(\mathrm{r}=$ $\left.0.941^{* *}\right)$, electrical conductivity of saturation extract $\left(\mathrm{r}=-0.991^{* *}\right)$ and sodium adsorption ratio $\left(\mathrm{r}=-0.959^{* *}\right)$ with seed cotton yield was registered (Table 3). Soil moisture is one of the major parameter of Vertisols contributing the productivity of crops and mainly governed by hydraulic conductivity of soil (Blokuis, 1989). The adverse effect of salinity and sodicity on crop yield might be related to nutritional imbalance and restricted water availability to the plants (Khandelwal and Lal, 1991). Data further reflected that $\mathrm{HC}$, which is the major postivie yield contributing factor had negative relationship with $\mathrm{pHs}(\mathrm{r}=-0.923), \mathrm{ECe}(\mathrm{r}=-0.922)$ and SARe $(\mathrm{F}-0.856)$ and this was also indicated by Balpande (1993). An enhancement in sodicity, rate of penetration of moisture of drying front declines and moisture changes in lower layers are much slower (Gupta and Verma, 1983).

Regression studies, revealed (Table 4) that based on 'R2' values negatively affecting soil attributes on yield of seed cotton follows the order as $\mathrm{ECe}>\mathrm{SARe}>\mathrm{pHs}$ and one unit increase / decrease in negative yield contributing factor of $\mathrm{pHs}, \mathrm{ECe}$ and SARe decreased / increased seed cotton yield by 8.27, 5.66 and 0.76 and one unit increase / decrease of $\mathrm{HC}$ increased or decreased seed cotton yield by 30.22 units respectively. In true sense, the individual effect is less reliable since a soil is a medium defined by interactions of various Soil characteristics. Therefore, the relationship between soil characteristic $\left(X^{\wedge}\right.$ to $\mathrm{X}_{\mathrm{n}}$ ) altogether and seed cotton yield are well established by MLR model i.e. ' $\mathrm{Y}$ ' 42.711.80** pHs-11.82** ECe+0.714* SARe$13.88^{* *}$ HC... .. .. .. $\quad \mathrm{R}^{2}=0.9997^{* *}$ describing 99\% variability in predicting the seed cotton yield grown in Sodic Haplusterts of Purna valley.

Table : 1 Yield of Cotton (q ha"1) as influenced by various amendments (Pooled means of 1996-97 to 1998-99)

\begin{tabular}{|c|c|c|c|c|}
\hline \multirow[t]{2}{*}{ Treatment } & \multicolumn{2}{|c|}{ Yield (qt ha"1) } & \multirow[t]{2}{*}{ Net Mondary Return (Rsha"1) } & \multirow[t]{2}{*}{$\mathrm{B}: \mathrm{C}$ ' ratio } \\
\hline & Seed cotton & Stalk & & \\
\hline Control & 7.15 & 23.97 & 6834 & 1.71 \\
\hline Gypsum $\AA 50 \%$ GR & 10.53 & 28.68 & 11571 & 1.95 \\
\hline Gypsum $100 \%$ GR & 10.97 & 30.72 & 9984 & 1.67 \\
\hline FYM@ 9 t ha"1 & 8.93 & 27.21 & 8853 & 1.67 \\
\hline PMC@2.5 t ha" & 8.94 & 27.30 & 10279 & 1.77 \\
\hline Gypsum@50% GR + FYM @ 5 t ha"1 & 12.09 & 33.74 & 13480 & 1.97 \\
\hline Gypsum 50\% GR + PMC @ 2.5 t ha"1 & 12.06 & 32.18 & 13980 & 2.06 \\
\hline $\mathrm{SE}(\mathrm{m}) \pm$ & 0.14 & 0.99 & - & \\
\hline CD at $5 \%$ & 0.45 & 3.07 & - & - \\
\hline
\end{tabular}

Table 2: Changes in pHs, ECe, SARe and HC of soil as influenced by various Amendments, (means of 1996-97 to $1998-99)$

\begin{tabular}{|l|c|c|c|c|}
\hline \multicolumn{1}{|c|}{ Treatment } & pHs & ECe $\left(\mathrm{dSm}{ }^{11}\right)$ & SARe & HC (cmhr"1) \\
\hline Contro & 8.35 & 2.70 & 18.30 & 0.12 \\
\hline Gypsum® 50\%GR & 7.97 & 2.10 & 13.40 & 0.19 \\
\hline Gypsum 100\%GR & 7.80 & 1.97 & 12.70 & 0.25 \\
\hline FYM @ 5 t ha" & 8.10 & 2.27 & 14.20 & 0.18 \\
\hline PMC @ 2.5 t ha & 8.20 & 2.30 & 15.10 & 0.19 \\
\hline Gypsum @ 50\% GR + FYM @ 5 t ha" & 7.820 & 1.80 & 12.20 & 0.29 \\
\hline Gypsum @ 50\% GR + PMC @ 2.5 t ha" & 7.90 & 1.80 & 11.30 & 0.23 \\
\hline SE(m) \pm & 0.20 & 0.13 & 1.10 & 0.02 \\
\hline CD at 5\% & 0.30 & 0.40 & 3.10 & 0.06 \\
\hline
\end{tabular}

Table 3 : Correlation ships of soil parameters and seed cotton yield

\begin{tabular}{|l|c|c|c|c|c|c|c|}
\hline Parameter & $\mathrm{pHs}$ & Ece & SARe & HC & Seed & Cotton (q ha-1) & yield \\
\hline pHs & 1 & & & & & & \\
\hline ECe & $0.943^{* *}$ & 1 & & & & & \\
\hline SARe & $0.198^{* *}$ & $0.981^{* *}$ & 1 & & & & \\
\hline HC & $-0.923^{* *}$ & $-922^{* *}$ & $-0.856^{* *}$ & 1 & & & \\
\hline Seed Cotton & $-0.941^{* *}$ & $-0.22^{* *}$ & $-0.959^{* *}$ & $-0.959^{* *}$ & 1 & & \\
\hline Yield (q ha'1) & & & & & & & \\
\hline
\end{tabular}


Table 4: Linear Regression equation in predicting seed cotton yield $(\mathrm{Y})$.

\begin{tabular}{|l|c|c|}
\hline Parameters $(\mathrm{x})$ & Linear Model & $\mathrm{R}^{z}$ \\
\hline $\mathrm{pHs}$ & $\mathrm{Y}=76.415-8.27^{* *} \mathrm{x}$ & $0.887^{* *}$ \\
\hline ECe & $\mathrm{Y}=22.18-5.66^{*} \mathrm{x}$ & $0.982^{* *}$ \\
\hline SAR & $\mathrm{Y}=20.63-0.759^{*} \mathrm{x}$ & $0.920^{*}$ \\
\hline HC & $\mathrm{Y}=3.83+30.22^{* *} \mathrm{x}$ & $0.82 \mathrm{~V}^{*}$ \\
\hline
\end{tabular}

\section{References}

Blokuis, W.A. 1989. Vertisols of the semi-arid tropics, Management of Vertisols for Improved Agricultural Production, Proceeding IBSRAM Inaugural workshop, 1985 ICRISAT (India), Feb. 18-22, : 37-44.

Gupta, R.K. and S.K. Verma, 1983. Water behaviour of black clay soils as influenced by degree of sodicity curr. Agric. $7: 14-121$.

Khandelwal, RB. and P. Lal, 1991. Effect of salinity sodicity and boron on irrigation water on the properties of different soils and yield of wheat. J. Indian Soc. Soil Sci. 39(3): 537-541.
Patel, K.P. and Bhajan Singh, 1991. A comparative study on the effect of gypsum, pressmud and pyrites on leachate composition, soil properties and yield of rice and wheat on a sodic soil. J. Indian Soc. Soil Sci. 39 () 154-159

Richards, L.A. (Ed.), 1954. Diagnosis and Improvement of saline and Alkali soils., USDA, Hand Book No. 60 Washington DC.

Sagare, R.N., R.L. Kalane and Y.S. Guhe, 1991. Characterization of salt affected Vertisols of Puma valley tract in Vidarbha region J. Maharashtra Agric. Univ. 16(3) :310-312.

Shivakant and Rajkumar, 1992. Effect of gypsum, pyrite, pressmud and FYM on soil properties and field of rice (Oryza sativa). Indian. J. agric. Sci. 62 (3): 191-195.

Tiwari, K.N. and D.N. Sharma, 1989. Soil salinity Research, AICRP, management of salt affected soils and use of saline water in Agriculture, CSAUAT, Kanpur: 89.

Varade, S.B., M.S. Palaskar and S.D. More, 1985. Characteristics and reclamation of salt affected Vertisols in canal commauds. J. Maharashtra agric. Univ. 10 (2): 115-120.

Verma, S.K. and R.K. Gupta, 1985. Relative effectiveness of pyrites and gypsum in reclaiming a sodic clay soil. $J$. Indian Soc. Soil Sci. 33 (2): 465-468. 